daily becoming more manifest. And it is in the studies leading to prophylaxis that the University mind can be made pre-eminent.

\section{THE UNIVERSITY OF CAMBRIDGE.}

By Professor G. D. Living, F.R.S. At the accession of Queen Victoria the University of Cambridge was still governed by the statutes of Elizabeth; tests were rigidly enforced; no one could be admitted to a degree or to a professorship until he had made a declaration of conformity, nor acquire a vote in the Senate until he had subscribed the $3^{6 \text { th }}$ canon. In two and a half centuries changes had been inevitable, but they had proceeded for the most part by easy gradations, and though they amounted on the whole to a revolution, the old forms were in most cases retained.

\section{Generat Education.}

The exercises in the schools by which the students publicly tested each other's knowledge and dialectic skill had been practically superseded for degrees in arts by a system of examinations of a very one-sided character, in which, so far as honours were concerned, the arts had no place and the sciences were represented only by those branches of natural philosophy which Newton and his successors had made classical. For a degree without honours candidates were still expected to study Homer and Virgil as the best examples of the art of poetry, and were examined in Locke's and Paley's philosophy; and for the last thirteen years there had also been an examination for honours in classical scholarship, but it was open only to those who had already obtained honours in mathematics. For the Master's degree no exercise was exacted, though the form of one still survived in " huddling" the candidates in a body through the schools, and asking them some question which was usually a joke.

The Teaching and the Trachers.

The general education of the students was entirely in the hands of the colleges, and college lectures embraced a wider range than the examinations for degrees, but no natural science except such as was mathematically treated. No student could get a degree unless he were presented as fit by his college, while the University awarded honours and checked the colleges by rejecting such as were grossly illprepared to graduate.

The professorships were for the most part honorary; the stipends attached to them, except in the case of Divinity, were hardly more than nominal ; the professors lectured as much or as little as they pleased, and, except in the faculties of Divinity, Civil Law, and Medicine, had no part in the education of the balk of the undergraduates. In the natural sciences. however, they were the only teachers, and they attracted to their classes those whose love of knowledge and of Nature was strong enough to draw them out of the ordinary routine. Theirs, too, were the only lectures experimentally illustrated. Farish, who had long given such lectures on mechanism, and had a good-sized class-attracted as much by the vigorous personality of the lecturer as by the excellence of his working models-had just been succeeded by an equally good lecturer, Willis. Henslow's unrivalled power of exposition and illustration exercised a wonderful fascination, and drew to his lecture room and herborising excursions all who cared for natural history, while Sedgwick's class-or such of them as could afford the hire of a hunter-followed him on horseback across the country on geological field days. Such studies were not the avenue to degrees or honours; but as the system of forcing the idle to work by means of examinations was not yet in vogue, they were pursued in a less specialised but, for the learners, more bealthy way than now prevails.

Airy had with great success given experimental lectures on optics and hydrostatics, and these were continued by Challis, who had just succeeded him as Plumian Professor; but Challis, though an excellent observer, was no experimenter, and too honest to take the advice that Airy is said to have given him-to ensure success by nailing the weight in showing Lagrange's proof of the principle of virtual velocities. Babbage at this time occupied Newton's chair, but neither he nor his immediate successor lestured, and it was not until
Stokes succeeded to it in 1849 that Challis's experimental lectures were discontinued.

Medical Students in 1837.

Medical students at Cambridge were few. The Calendar for 1837 records that in the year preceding five had taken the degree of M.B., and ten the licence to practise. This licence was given to graduates in arts who had gone through the prescribed course of study, and they often pursued their medical studies in London, so that the average number studying medicine at Cambridge was hardly more than fifteen or twenty all told. They were obliged to attend the lectures on botany chemistry, and anatomy. Cumming gave fifty experimental lectures on chemistry, of which about one-third were on electricity (then considered part of chemistry), and another third on the then just developing branch of organic chemistry. The professor had two rooms for his own use, fitted entirely at his own cost, but there was no laboratory of any kind in which undergraduates could carry on experimental work, either in chemistry or in any other branch of physics. Clark gave a course of fifty lectures on anatomy, and dissection was carried on in the anatomical theatre, for want of proper room, whenever subjects could be had; but the restrictions of the Anatomy Act, and the prejudices of the community, made the supply very precarious. Only a year or two had passed since the removal of an unclaimed body from the hospital to the anatomy school had caused a riot, in which the mob tore up the pavement, smashed the neighbouring college windows, broke into the anatomical museum, and did great damage to the specimens. From that time no bodies have ever been taken from the hospital for dissection. The Regius Professor of Physic lectured on pathology and the practise of physic, and the Downing Professor on morbid anatomy, and the hospital staff gave clinical lectures on medicine and on surgery; but students were expected to, and did, complete their medical education elsewhere, usually at some London hospital. A candidate for the medical degree was examined by the professors, and had to keep an Act at which he read an original thesis on some medical question, and had to answer in public the objections of one or more fellow students, as well as any questions that might be put by the presiding professor. There was no degree in surgery, and no professorship of surgery. Physiology, in its then undeveloped state, was taught along with anatomy. Not only were there no laboratories, but many of the professors had no lecture rooms, except such as they provided for themselves, and the collections of natural history could not be displayed, or even made generally accessible, for want of room.

\section{MUSEUMS}

The only museum built for the purpose, that of anatomy had been erected about - four years, and contained the collection made by Sir B. Harwood during his tenure of the professorship from 1785 to 1814 . and that of Dr. Macartney, purchased in 1836 , as well as Clark's specimens of comparative anatomy; but it was a very poor building, and soon became overcrowded with the skeletons which Clark's assiduity accumulated. There was a botanic garden in the middle of the town, and a herbarium so ill-housed as to be greatly injured by damp. Woodward's cabinets of fossils were stowed in a dark room ; and Sedgwick, who had promised when elected professor in 1818 that, as he had hitherto never turned a stone, he would henceforth leave no stone unturned, had kept his word and accumulated a large store of specimens from every stratum in England, but was obliged to keep a great part of them in his own rooms in college for want of a museum. The mineralogical collection was in like case. A proposal was, indeed, made this year (1837) to rebuild the library with the addition of lecture rooms and museums, but it was three years later before even a small portion of this scheme was carried out. The delay was caused by lack of funds, which had to be obtained by subscription. This may well seem incredible to those who are not well acquainted with the University; but apart from trusts for specific purposes, such as scholarships and the like, the whole endowment of the University was not more than about $£ 1,000$ a year, and the fees for matriculation and degrees brought in at ou $t, 2,000$ a year more. The library was supported by a tax of $6 \mathrm{~s}$. a head on all members of the University, and the proctors and other officers were paid by fees, so that the income available for 
general purposes was only about $£ 3,000$ a year. On the other hand, the college endowments were large, and it was to the colleges that the students paid the bulk of their fees, and from them received in return tuition and supervision. But the colleges did not provide any instruction in natural sciences, or give scholarships or fellowships for proficiency therein, and in 1837 were not at all inclined to help the University with money, content with a system which had produced such philosophers as Wollaston, Fox-Talbot, Herschell, and Whewell, and in that very year had brought out Sylvester and Green, and within the next few years was destined to bring out Stokes, Cayley, Adams, and Kelvin.

Natural Science in 1837.

There were, nevertheless, some who followed natural science, and they had their hearts in it. The Philosophical Society-for the discussion and publication of papers on physical science-had existed nearly 20 years, and had done good service to science not only in that way but also by maintaining the only zoological museum in the University; and

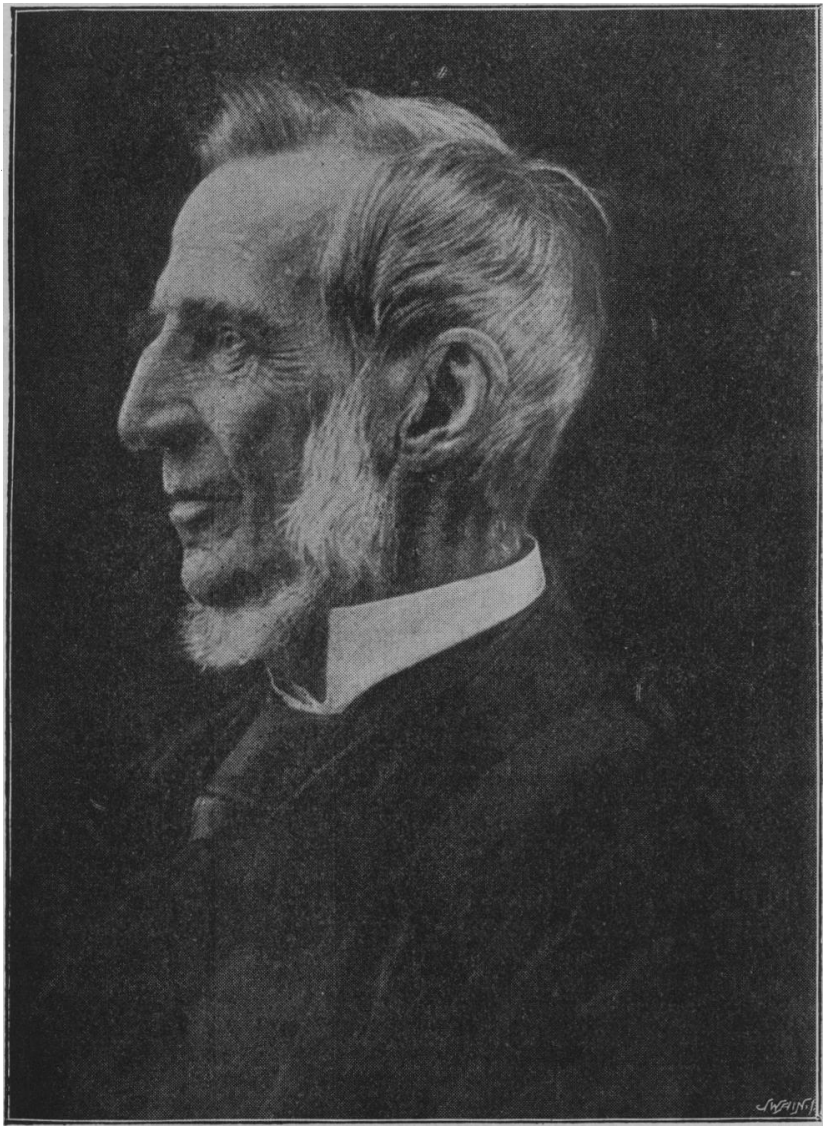

Sir George Paget.

in 1337 a club of naturalists, named after Ray, instituted weekly conversational meetings to keep up the interest in natural history aroused by the weekly receptions which Henslow had been wont to hold at his house until he was given a benefice in Suffolk, and ceased to reside in Cambridge for more than one term in the year.

The conflict of theologians with science, rife outside over the Mosaic cosmogony, was quiet enough within the University. Most of the scientific professors, even the professor of anatomy, were clergymen, and the traditional Cambridge respect for inductive philosophy compelled the theological faculty, if they did not entirely side with the followers of natural science, to give them a fair field.

The spirit of reform pervading the community was felt in the University. A large number of influential residents, including not only scientific professors but such men as Musgrave (afterwards Archbishop of York), and Thirlwall (afterwards Bishop of St. David's), had recently, but in vain, petitioned Parliament for the relaxation of the religious tests; and, soon after, Whewell and others made proposals for widening the examinations for honours; but no change of any importance was made during the first decade of Victoria's reign, except that Humphry came as surgeon to the hospital, and undertook the teaching in human anatomy as assistant to Clark, who thenceforth devoted himself to comparative anatomp.

The Brginning of a Revolution.

In 1847 the Prince Consort was elected, after a sharp contest, Chancellor of the University. He took a real interest in its welfare, made friends of many of the leading men, and had Sedgwick for his University secretary, and though, with much tact, in view of the prejudice against German methods, he kept in the background, there is no doubt that he exerted his influence in favour of the new honour triposes in the moral and natural sciences which, mainly through the advocacy of Whewell, were sanctioned by the Senate in 1848 , and com-

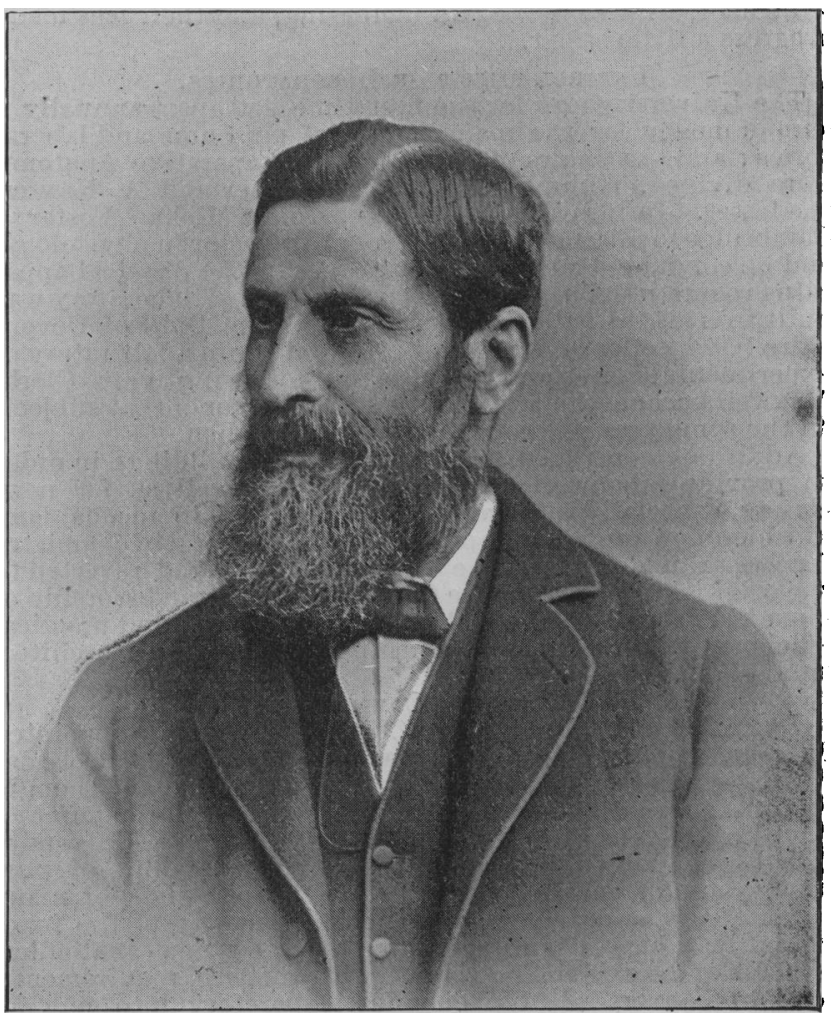

Sir George Murray Bumphry.

menced in $185 \mathrm{I}$. At the same time attendance on a course of some professors' lectures was exacted of all candidates for an ordinary degree. This was the beginning of a revolution, for, though only six names appeared in the first Natural Science Tripos, more men in 1896 took honours in it than in any other tripos except the Classical. In the next year one of the above-mentioned six, though as yet only a Bachelor of Arts, with the sanction of the Vice-Chancellor opened, at his own expense, a laboratory for the instruction of the medical students in practical chemistry. This was the first attempt to supply training in experimental work, and was followed by a long struggle with impecuniosity on the part of the University-a struggle not yet over-to provide means of instruction commensurate with the growth of knowledge. In $1853 \mathrm{St}$. John's College was the first to appoint a lecturer in natural science and to build a small chemical 
laboratory; and in the same year the Senate took in hand the erection of museums and lecture rooms, though for lack of funds it was ten years ere the first stone of them was laid.

A Royal Commission.

Meantime a Royal Commission of Inquiry had been issued, which was followed in 1856 by an Act of Parliament under which the University and colleges received new statutes. Unfortunately the Commissioners failed to carry out a scheme for making the colleges contribute to the needs of the University, and the resources of the latter were unequal to the erection of more than a part of the new museums, or to raise the stipends of the professors of natural science beyond the modest figure of $£ 300$ a year, leaving them to provide at their own expense the whole of the apparatus required either for lectures or research. Indeed, the Museum of Comparative Anatomy could not have been built but for the liberality of the Professor of Anatomy in lending the money for it at a nominal rate of interest. In 1865 the collections of comparative anatomy, botany, and mechanism were removed to the new museum, and out of the old building were constructed a dissecting room and a chemical laboratory, and from this time the expansion of the University began. The number of students, which during and after the Crimean war had fallen to about I,500, was now again increasing, and their fees made progress a little easier.

Establishment OF LABoratories.

The University now for the first time set apart annually a sum of money for the maintenance of museums and laboratories ; and the Chairs of Human and Comparative Anatomy were divided, Humphry taking the former and A. Newton the latter. In 1870 Trinity College brought Michael Foster to Cambridge to fill a new college office of prelector in physiology, and he conducted an enthusiastic class in the physical apparatus rooms until the existing physiological laboratory was built in 1878. In the same year (1870) the Duke of Devonshire (Chancellor) offered to build and equip a laboratory of experimental physics, and in the following year ClerkMaxwell became the first Cavendish Professor of that subject. In the same year religious tests were abolished.

Additions continued to be made to the buildings in order to provide laboratories for increasing, as well as for new, classes, especially in animal morphology and in mechanism, of which new professorships were instituted, and in chemistry for Dewar, under whom the Jacksonian chair had reverted to the original intention of the founder to be a professorship of chemical science. Money, however, was scarce, and practical efficiency had to be secured at the expense of all architectural effect.

ANOTHER CoMmisston.

By an Act of Parliament new Commissioners were appointed in 1877 , who made new statutes under which the Colleges contribute to the common fund of the University, and though in consequence of the agricultural depression, the amount of that contribution has been much reduced, the University has been enabled to establish new professorships of physiology and of pathology, to increase the stipends of many other chairs, and, by borrowing on the security of the fund to build a new chemical laboratory, and new anatomical schools on a scale commensurate with modern requirements, and to convert the old chemical laboratory into one for pathology; but the professorship of surgery, established in 1883, was held by the late Sir G. M. Humphry without stipend, and the engineering laboratory has been built by subscription, the present Chancellor contributing $f_{\mathrm{I}}, 000$. For the Geological Museum, as a memorial of Sedgwick, a large sum was raised by subscription after his death, but the University has not yet been able to provide the additional sum required to erect it.

The Extension of Teaching.

This continual expansion has, moreover, involved the creation of a large staff of lecturers and demonstrators, who mostly get very moderate remuneration. Whereas in 1837 9 professors and 3 or 4 others were engaged in teaching natural science or medicine, there are in 189715 professors, 2 readers, I5 University lecturers, and as many other recognised teachers, as well as 24 demonstrators so engaged. Whereas in 1837 no honours were given for natural science, except it were mathematically treated, now nearly 100 every year obtain the degree of B.A. with honours in natural science, and half as many more take up natural science for an ordinary degree. Whereas then there were fewer than a score of medical students, there are now more at Cambridge than in any other single medical school in England.

In 1837 the programme of lectures for medical students included only anatomy and physiology, botany, chemistry, pathology, and practice of physic, the programme for 1897 , owing to the subdivision of some of the foregoing subjects, and the addition of others such as pharmacology and therapeutics, surgery and midwifery, medical jurisprudence, hygiene, and bacteriology, has become too long to quote. Whereas in 1837 there was not a single laboratory for students, there is now no important branch of natural science except psychology which has not a laboratory, in many cases ample and well equipped, and in others, such as those of pathology, bacteriology and pharmacology, temporary until the University has funds for their improvement, but in all cases used not only for education but also for research. For these changes we have in the main to thank two men-Sir George Paget, for many years Regius Professor of Physic, and Sir George M. Humphry.

\section{EXAMINATIONS}

It goes without saying that examinations have kept pace with the extension of teaching. In 1837 the only examinations for honours were in mathematics, pure and applied, and in scholarship, subjects which can hardly be crammed up, but in which the value of the answers can be gauged by an exact scale. It was the success with which these examinations were conducted, together with the scrupulous fairness with which the prize fellowships were awarded, that paved the way to competitive examinations for posts in the Civil Service, and the examination fever that has ensued. Candidates can now compete for honours in almost every branch of knowledge, but in few of them can the merits of candidates be estimated by examination with as much nicety as in mathematics, and it is pretty well understood that to learn a subject well is not the same thing as to learn to pass an examination in it. In natural science the examinations always include practical work, and for medical degrees the University led the way in introducing clinical examination. In 1867 State Medicine was introduced into the examination for the M.D. degree, and in 1875 was held the first examination for the Diploma in Public Health, open to all whose names were on the Medical Register. The old exercises for medical degrees-namely, the pablic reading of an original essay by the candidate, and subsequent oral questioning, are fortunately still retained, and it may be said that the examinations fairly reach the limit of utility. Fellowships are awarded for distinction in learning of every kind, and with as much fairness as ever; but it is significant that they are no longer awarded merely by examination, but much more on the merits of the original work done by the candidates s in which the men of science can, and do, hold their own.

\section{The Encovragement of Trchnical Soirnce.}

It is remarkable that the great expansion of scientific study at:Cambridge has not been made at the expense of other learning, but has been achieved in spite of ever-growing demands' for developments in literature, in art, and in other departments. The University is sometimes accused of not encouraging technical science, but the eagerness of poung men to take to any particular professional work depends not so much on the teacher as on the remuneration it commands in the world. Cambridge does turn out the ablest electrical engineers, and would do as much for many other arts if it were not for the distrust of the University which, unhappily, is entertained by the trading class, a distrust exemplified by the fact that, though there is at Cambridge a growing school of scientific agriculture, farmers cannot be bribed by the scholarships, freely offered by many county councils, to send their sons to take advantage of it. The change which has come over the University during the latter half of Victoria's reign has been too great to be at once understood by the public, but as there is no other place in the kingdom where physical science is so large a factor of general, as distinct from professional education, it is through the better appreoiation of such knowledge by the rising generation that further advances may, it is hoped, become possible. 